\title{
Limited human-to-human transmission of avian influenza A(H7N9) virus, Shanghai, China, March to April 2013
}

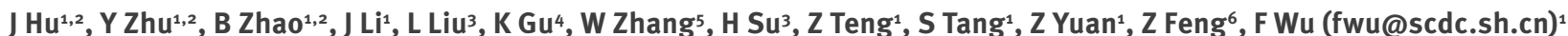

1. Shanghai Municipal Center for Disease Control and Prevention, Shanghai, China

2. These authors contributed equally to this article

3. Chinese Academy of Medical Sciences and Peking Union Medical College, Beijing, China

4. Jin-an District Center for Disease Control and Prevention, Shanghai, China

5. Huashan Hospital, Fudan University, Shanghai, China

6. Public Health Emergency Center, Chinese Center for Disease Control and Prevention (China CDC), Beijing, China

In April 2013, two members of one family were successively confirmed as cases of avian influenza $A\left(\mathrm{H}_{7} \mathrm{~N}_{9}\right)$ virus infection in Shanghai, China. Respiratory specimens from the two cases and their close contacts were tested using real-time reverse-transcription (RT)-PCR. Paired serum specimens from contacts were tested by haemagglutination inhibition assay and microneutralisation test. The index patient developed severe pneumonia. Her husband presented with pneumonia shortly thereafter. Both cases had highly similar clinical features and infection with $\mathrm{A}\left(\mathrm{H}_{7} \mathrm{~N} 9\right)$ virus was confirmed in both cases by genetic analysis. Phylogenetic analysis revealed a high level of similarity between the sequences from the two patients and environmental samples collected from wet markets in Minhang and Changning districts. Six samples from the Changning wet market were confirmed as $\mathrm{A}\left(\mathrm{H}_{7} \mathrm{~N} 9\right)$ positive. Of 27 close contacts, one developed mild respiratory symptoms and another tested positive for $\mathrm{A}\left(\mathrm{H}_{7} \mathrm{~N} 9\right)$ antibodies, but both were negative by real-time RT-PCR. The other 25 close contacts of both cases were $A\left(H_{7} \mathrm{~N}_{9}\right)$ negative. Limited human-to-human transmission of the virus most likely occurred in the family cluster. However, other close contacts did not test positive for the virus, suggesting limited potential for extensive human-to-human transmission of the virus.

\section{Introduction}

A novel influenza virus was isolated from two fatal human cases in Shanghai, China in March 2013 [1]. Genomic sequencing indicated that the recombinant virus belonged to the influenza A subtype $\mathrm{H}_{7} \mathrm{~N}$ 9. Low pathogenic avian influenza $A\left(\mathrm{H}_{7} \mathrm{~N} 9\right)$ virus infection occurs in animals and is mostly asymptomatic [2] but had not been previously reported in humans [3]. Illness caused by this novel virus in humans is characterised by a sudden onset of high fever $\left(\geq 39{ }^{\circ} \mathrm{C}\right)$ and respiratory symptoms, followed by a progressive decline in lung function. The global impact of influenza $A\left(\mathrm{H}_{7} \mathrm{~N}_{9}\right)$ is not yet well understood and a pandemic was feared as the number of cases continued to increase in China [4].

Past epidemiological evidence has demonstrated that infection with avian influenza $\mathrm{A}\left(\mathrm{H}_{5} \mathrm{~N}_{1}\right)$ virus may occur by handling or coming into contact with infected poultry or birds [5]. Unprotected exposure to critically ill patients may have led to human-to-human transmission of $\mathrm{A}\left(\mathrm{H}_{5} \mathrm{~N}_{1}\right)$ virus in Thailand in 2004 [6,7]. Familial clustering of $A\left(\mathrm{H}_{5} \mathrm{~N}_{1}\right)$ virus infection was also observed in Jiangsu Province, China in 2007 [8]. As for $A\left(\mathrm{H}_{5} \mathrm{~N}_{1}\right)$, human-to-human transmission of $\mathrm{A}\left(\mathrm{H}_{7} \mathrm{~N} 9\right)$ virus merits further study.

Three family clusters of $\mathrm{A}\left(\mathrm{H}_{7} \mathrm{~N} 9\right)$ virus infection were reported in 2013: all cases were blood relatives $[9,10]$. Due to the limited number of cases, possible human-to-human transmission could not be ruled out. More and more cases have been reported in 2014 in Zhejiang, Guangdong, Jiangsu and Shanghai provinces of China, indicating that $\mathrm{A}\left(\mathrm{H}_{7} \mathrm{~N} 9\right)$ viruses were circulating asymptomatically among natural hosts and that the transmission route of this virus is complex $[4,11]$. As of 17 June 2014 , 247cases have been reported in 2014 [12]. Evidence of human-to-human transmission is important for making recommendations on vaccination and treatment, as how readily the virus moves between people determines what kind of preventive measures and policies should be enacted.

We report the results of an investigation into a family cluster of cases with $\mathrm{A}\left(\mathrm{H}_{7} \mathrm{~N} 9\right)$ virus infection in Shanghai, China. A couple who presented with severe pneumonia were hospitalised in April 2013: both were confirmed as $\mathrm{A}\left(\mathrm{H}_{7} \mathrm{~N} 9\right)$ positive. Epidemiological, clinical and laboratory findings are described and provide 
clues to the possibility of human-to-human transmission - data vital to the prevention and control of reemerging human infection with $\mathrm{A}\left(\mathrm{H}_{7} \mathrm{~N} 9\right)$ virus.

\section{Methods}

\section{Epidemiological investigation}

The Shanghai Municipal Center for Disease Control and Prevention (SCDC) was informed about the index case, on 3 April. Investigative staff from the SCDC interviewed the couple the same day, during Case A's hospitalisation to verify the reported exposure history starting one week before the onset of symptoms and to establish event timelines. A standardised structured questionnaire was used to collect demographic information, information on syndromes and symptoms, epidemiological history (including exposure to poultry and livestock, extent of outdoor activity and poultrymarket visits) and information on close contacts. An epidemiological investigation, identification and active surveillance of close contacts were initiated on 3 April immediately once the SCDC had been informed about the index case.

Medical records were also reviewed for the time of symptom onset and progression of the illness. Nasal swabs and pharyngeal swabs from the two patients were collected during their hospitalisation.

Close contacts were defined as individuals known to have been within 1 metre or to have had contact with the serum, respiratory or faecal secretions of a case of $A\left(\mathrm{H}_{7} \mathrm{~N} 9\right)$ infection without having used effective protective equipment at any time from one day before the symptoms onset of the case to the day the case was placed in isolation or died [13]. The close contacts were monitored twice daily for fever and respiratory symptoms via repeated interviews over the 10 days after their last exposure to the cases. Nasopharyngeal swabs were collected if febrile respiratory symptoms appeared during observation. Paired sera were collected from close contacts during both acute and follow-up phases ( $\leq 1$ week and 3-4 weeks, respectively, after their last exposure to the cases).

Households and places known to have been visited by the cases in the seven days before the onset of symptoms were surveyed to assess the source of possible environmental exposure. These included the Taiyang (TY) wet market (an open market selling fish, poultry, pork, etc.) in Changning district, which the index case often visited before the onset of symptoms. Because poultry at the TY wet market came from a wholesale market that also supplied Ruili (RL) wet market (in Minhang district), we also collected environmental samples from this wet market.

Faeces samples and tracheal and cloacal swabs were collected from pigeons raised in the community where the patients resided. Sera samples were also collected from some of these pigeons to test serologically for $\mathrm{A}\left(\mathrm{H}_{7} \mathrm{~N} 9\right)$ antibodies.

Environmental samples (including chicken faeces, wastewater from a slaughterhouse, swabs from a chicken cage surface and poultry chopping boards) from the TY and RL wet markets were collected according to the standard operation procedures (SOPs) of the China Center for Disease Control and Prevention (CDC). All samples were placed in sterile viral transport medium at $4^{\circ} \mathrm{C}$ and transferred to an SCDC laboratory for $\mathrm{A}\left(\mathrm{H}_{7} \mathrm{~N} 9\right)$ virus detection within two hours.

All investigations were conducted in accordance with the policy approved by the SCDC ethics committee. Informed consent was obtained from patients and close contacts.

\section{Laboratory testing}

Total nucleic acid was isolated from each sample (200 $\mu \mathrm{l})$ using MagNA Pure LC 2.0 (Roche, Switzerland) with the MagNA Pure LC DNA Isolation Kit (Roche, Germany). Real-time reverse transcription (RT)-PCR, to detect influenza $\mathrm{A}, \mathrm{H} 7$ and $\mathrm{N}$, was performed according to the SOPs of the World Health Organization (WHO) [14].

In order to explore the genetic relationship between the two cases, total genomic segments were amplified using RNA isolated directly from original specimens as described previously [15]. The $A\left(\mathrm{H}_{7} \mathrm{~N} 9\right)$-positive environmental samples collected from the TY wet market in Changning were sequenced simultaneously. On the basis of the threshold cycle value, we also chose one $\mathrm{A}\left(\mathrm{H}_{7} \mathrm{~N}\right.$ ) $)$ virus-positive environmental sample, collected from the RL wet market for sequencing. To facilitate the phylogenetic analysis, sequences of novel $A\left(\mathrm{H}_{7} \mathrm{~N}\right.$ ) $)$ viruses from the two members of this family and environmental samples collected in Shanghai in 2013 were downloaded from the Global Initiative on Sharing All Influenza Data (GISAID) EpiFlu database (Table 1). In addition, the standard $A\left(\mathrm{H}_{7} \mathrm{~N} 9\right)$ strain $\mathrm{A} /$ Anhui/01/2013 [1] was also analysed. Sequence similarity analyses were performed with MegAlign method [16] in the Lasergene 7.01 software package. We used MEGA software (version 5.05) [17], multiple alignments by MUSCLE algorithm (a multiple sequence alignment method with reduced time and space complexity) and phylogenetic trees constructed by neighbour-joining method to estimate the viral gene relationship with selected influenza A virus strains obtained from GISAID.

The $\mathrm{A}\left(\mathrm{H}_{7} \mathrm{~N} 9\right)$ antibody titre was determined in paired sera from close contacts using the haemagglutination inhibition ( $\mathrm{HI}$ ) assay from the China CDC [18]. A microneutralisation (MN) test was performed for serum samples with titres $\geq 40$. Two assays were conducted according to WHO SOPs $[19,20]$; the standard antigen used in the two assays was produced from $A\left(\mathrm{H}_{7} \mathrm{Ng}\right)$ isolates $\left(\mathrm{A} / \mathrm{AH} / 1 / 2013\left(\mathrm{H}_{7} \mathrm{~N} 9\right)\right)$. 


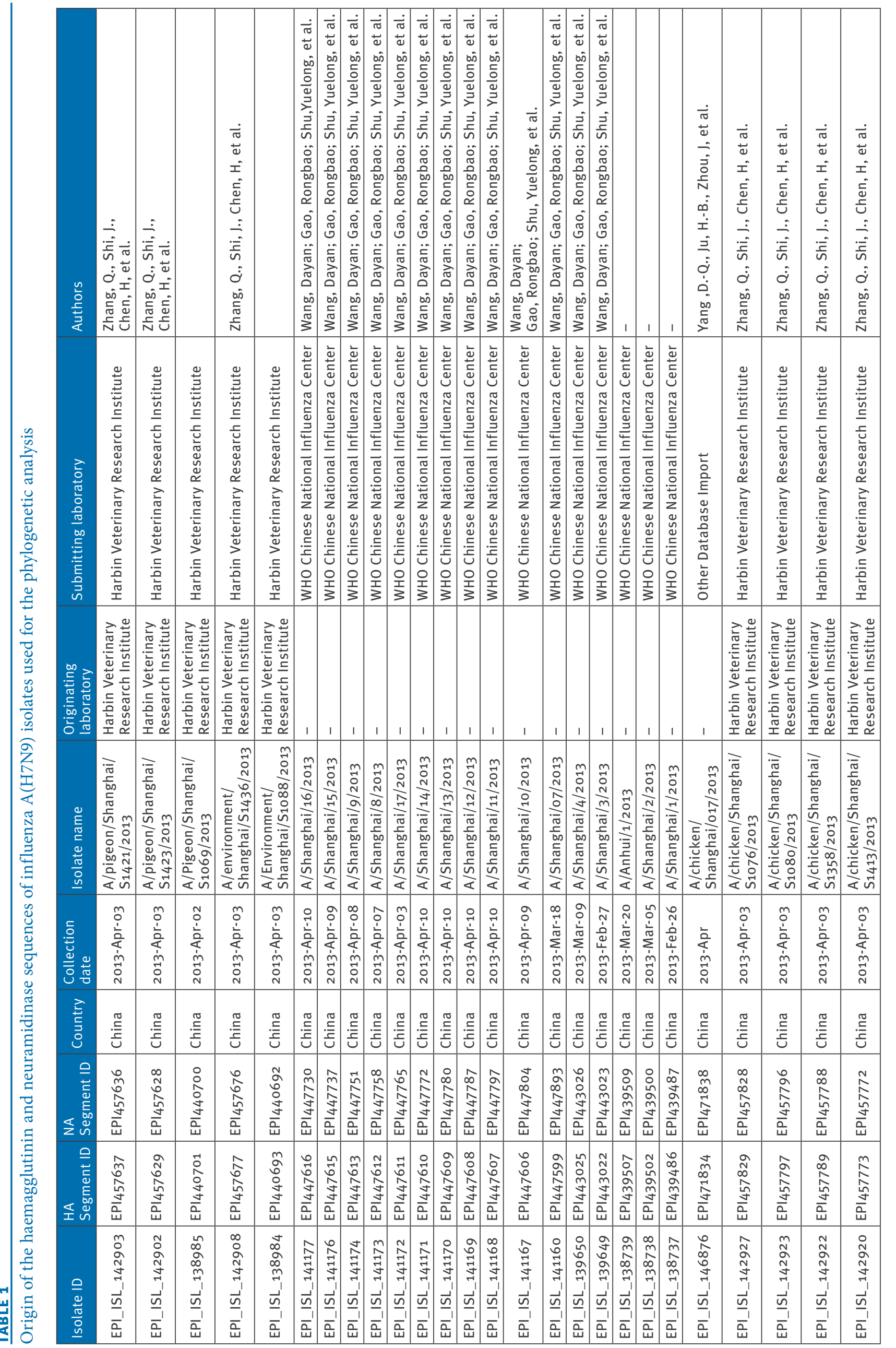


Timeline of key events during illness of two cases of influenza A(H7N9) virus infection, Shanghai, China, March-June 2013
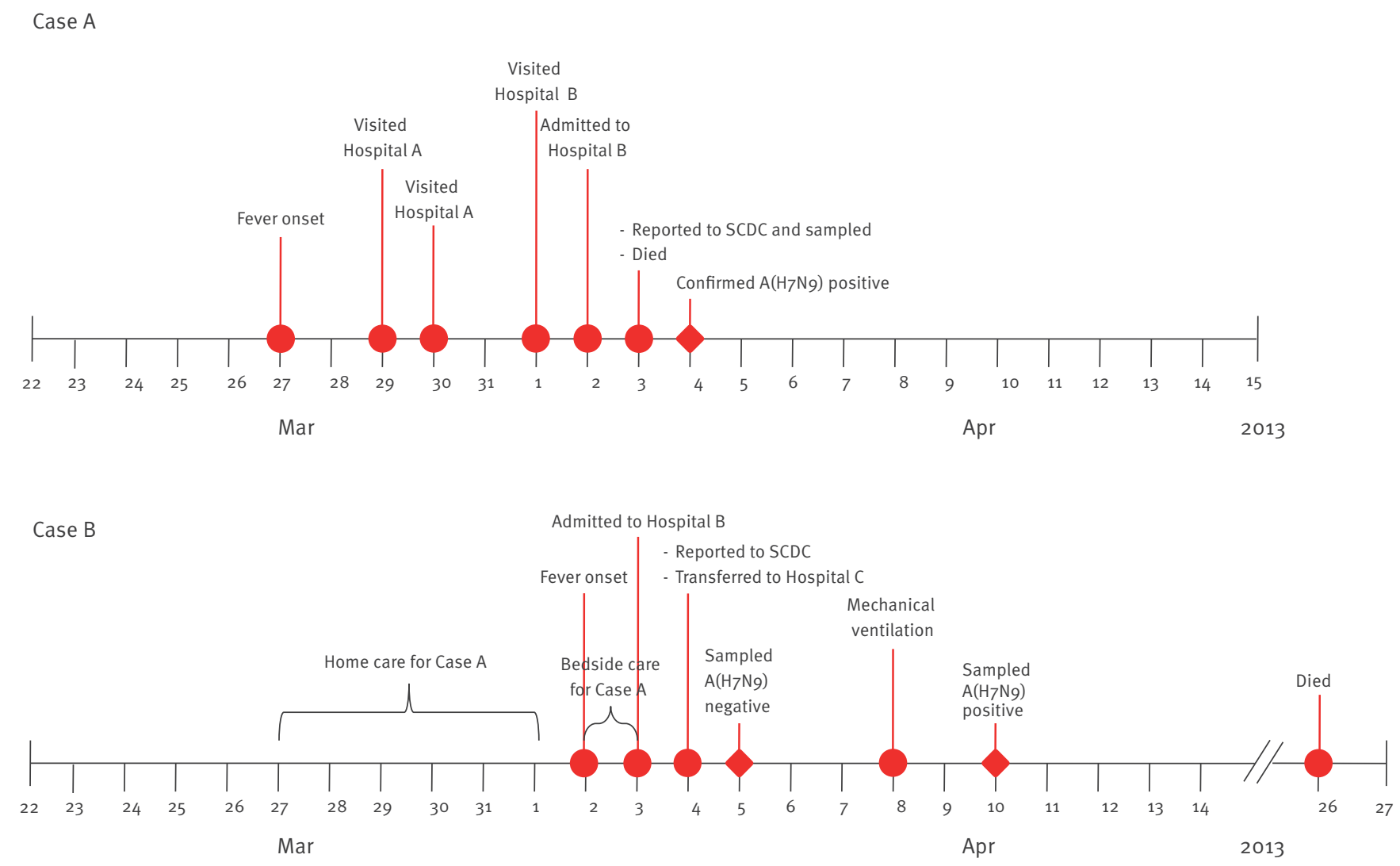

SCDC: Shanghai Municipal Center for Disease Control and Prevention.

\section{Results}

\section{Cases $\mathrm{A}$ and $\mathrm{B}$}

Case $A$, the index case, in this family cluster was a woman in her early $50 \mathrm{~s}$ who lived in the Changning district of Shanghai with her husband (Case B). The patient was very weak and developed a low-grade fever, chills and arthralgia on 27 March 2013. She took acetaminophen and aminophenazone at home the following day and visited the local hospital (Hospital A) on 29 and 30March. Chest X-ray showed right-lower-lobe pneumonia. She was given a three-day prescription of ceftazidime and levofloxacin for symptomatic and anti-infection treatment. However, she visited a second hospital (Hospital B) with a temperature of $39.5{ }^{\circ} \mathrm{C}$ on 1 April. Initial testing showed that her white blood cell count was normal; she received further antibiotic therapy with ceftriaxone and ofloxacin. She was admitted the following day with a diagnosis of severe pneumonia and acute respiratory distress syndrome (ARDS). Tests upon admission revealed leucopenia and hypoxaemia. A lung computerised tomography scan showed diffuse bilateral lung infiltrates associated with right pleural effusion. Despite endotracheal intubation and administration of oseltamivir (75 mg twice a day via a nasogastric feeding tube, a total of two doses of $75 \mathrm{mg}$ before her death) and corticosteroids, the patient died on 3 April.

Case B, Case A's husband who was in his mid-50s, developed a fever on 2 April. He was admitted to Hospital Bon 3 April with a temperature of $39.5{ }^{\circ} \mathrm{C}$, rhinorrhoea, dry cough and sore throat. A chest X-ray showed bilateral lower-lobe infiltrates. On 4 April, he was transferred to another hospital (Hospital C, where suspected or confirmed $\mathrm{A}\left(\mathrm{H}_{7} \mathrm{~N} 9\right)$ cases were treated). He began treatment with oseltamivir (75 mg orally twice daily from 3 to 10 April). Although he was mechanically ventilated on 8 April, he also developed ARDS, on 11 April. He progressively deteriorated in the hospital until his death on 26 June.

A timeline of key events is shown in Figure 1.

On 4 April, $A\left(\mathrm{H}_{7} \mathrm{~N}_{9}\right)$ virus was detected by real-time RT-PCR of RNA extracts from respiratory specimens taken from Case A during the acute phase of her illness. Real-time RT-PCR of RNA extracts from pharyngeal swabs from Case $B$ were negative for $A\left(\mathrm{H}_{7} \mathrm{~N}_{9}\right)$ on 
Phyloygenetic tree of avian influenza A (H7N9) virus haemagglutinin and neuraminidase sequences for two cases in a family cluster, Shanghai, China, March-June 2013

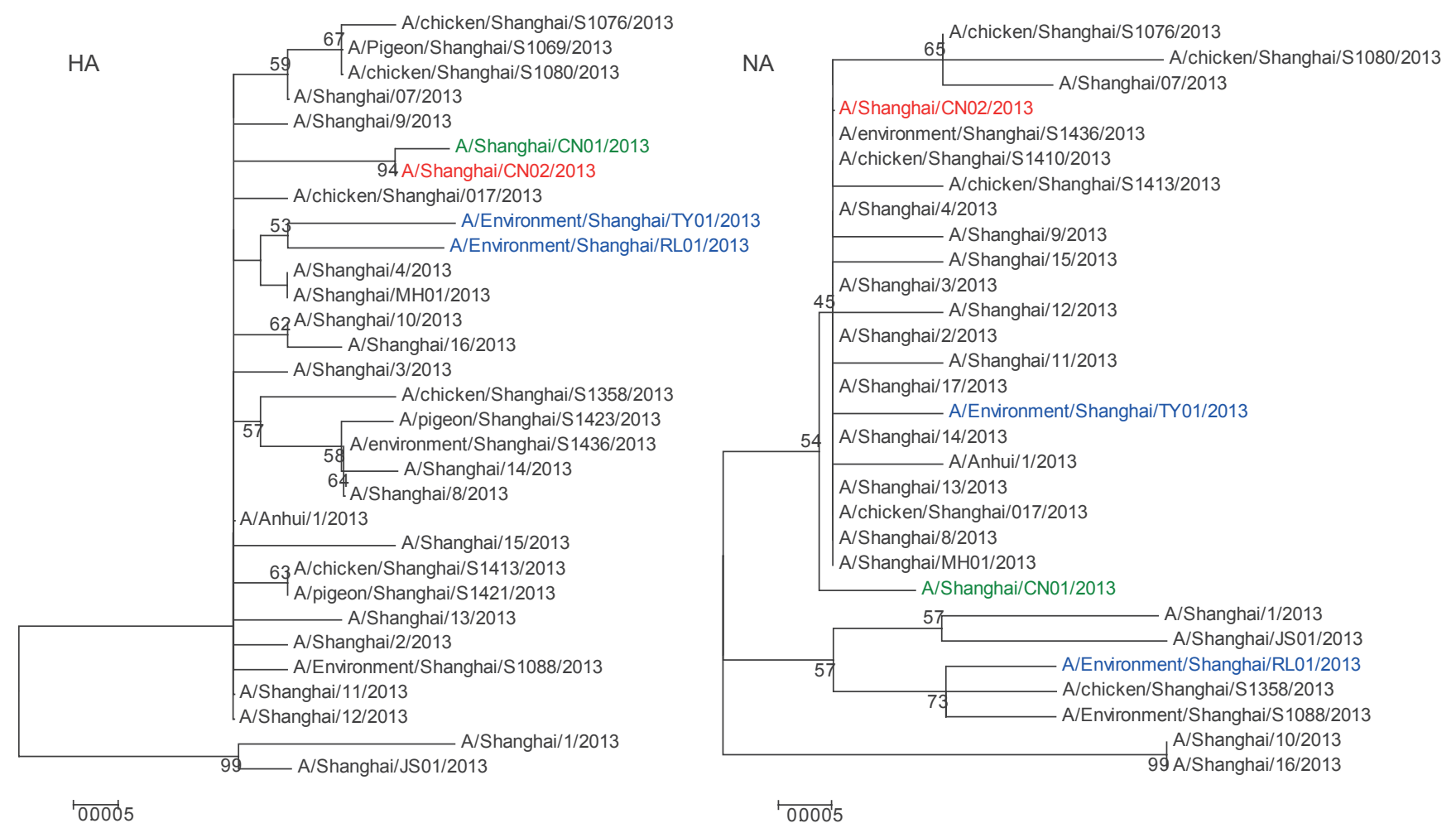

HA: haemagglutinin; NA: neuraminidase.

Multiple alignments were constructed by using the MUSCLE algorithm (a multiple sequence alignment method with reduced time and space complexity) of MEGA software version 5.05. Phylogenetic trees were constructed by using the neighbour-joining method with bootstrap analyses of 1,000 replications. Bootstrap values are shown in the nodes. Sequences of CNo1 are shown in green, sequences of CNo2 are shown in red, and sequences of TY01 and RL01 are shown in blue. The scale bar indicates base substitutions per site.

5 April, whereas testing of pharyngeal swabs taken on 10 April confirmed the presence of the $\mathrm{A}\left(\mathrm{H}_{7} \mathrm{~N} 9\right)$ virus.

The index case had had surgery several years before this infection, but had otherwise been in good physical condition before symptom onset. She had not eaten poultry or come into direct contact with live poultry or individuals with febrile respiratory symptoms during the two weeks before symptom onset. The pork and vegetables that made up her daily diet were purchased in a supermarket and the TY market near her home. Live poultry were sold and slaughtered at this wet market that Case A visited daily. The area where live poultry were available was approximately 2 metres from the vegetable stands she often visited. Although homing pigeons were raised on roofs adjacent to the couple's residence, neither had come into contact with pigeons or their faeces. No other birds or poultry were raised in her residential quarter and no live poultry was ever brought home.

Case B had not visited any wet market 14 days before symptom onset. He reported no history of live poultry exposure and had not been in contact with symptomatic individuals except for Case A. He too had not eaten or purchased live poultry or poultry products during the two weeks before the onset of his symptoms. He had participated in the care of Case A, providing unprotected care, including bedside care day and night either at home or in the hospitals between 27 March and 3 April.

\section{Environmental samples}

A total of 12 faeces samples and 51 tracheal or cloacal swabs from 27 pigeons in the couple's community collected on 13 April were negative for $A\left(\mathrm{H}_{7} \mathrm{~N} 9\right)$ by realtime RT-PCR. A total of 27 serum samples from these pigeons were negative for $\mathrm{A}\left(\mathrm{H}_{7} \mathrm{~N} 9\right)$ using the $\mathrm{HI}$ assay.

Environmental sampling of markets was carried out on 4 April. As all poultry markets in Shanghai were closed on 5 April on order from the Shanghai Municipal Government in response to the $A\left(\mathrm{H}_{7} \mathrm{~N} 9\right)$ outbreak [21], samples from chickens in the TY market were unavailable at the time of sampling (the live poultry stand in the market closed on 4 April). However, six samples 
collected from a poultry chopping board, two chicken faeces samples and two water samples from the live poultry trading area on the day the TY market closed were positive for influenza $A$ and five samples from the poultry chopping board and one chicken faeces sample were positive for $\mathrm{A}\left(\mathrm{H}_{7} \mathrm{~N} 9\right)$ by real-time RT-PCR.

Five samples from RL wet market, including one chicken faeces, one swab from a pigeon cage surface, one swab from duck cage surface, one swab from a pork chopping board and one waste-water sample from a slaughterhouse, were tested for influenza $A$ and $A\left(\mathrm{H}_{7} \mathrm{~N} 9\right)$ by real-time RT-PCR. All five samples were positive for influenza $A$. Four samples were also positive for $A\left(\mathrm{H}_{7} \mathrm{~N} 9\right)$ : the swab from the pork chopping board was negative.

The viruses detected in the patients and the chicken faeces samples from the TY and RL wet markets were designated as follows:

- A/Shanghai/patient $\mathrm{CNo}_{2} / 2013$ ( $\left.\mathrm{H} 7 \mathrm{~N} 9\right)$, from Case A (referred to hereafter as $\mathrm{CNO}_{2}$ );

- A/Shanghai/patient $\mathrm{CN}_{01 / 2013}(\mathrm{H} 7 \mathrm{~N} 9)$, from Case B (CNo1);

- A/Environment/Shanghai/TYo1/2013 (H7N9), from Changning TY market (TYo1);

- A/Environment/Shanghai/RL01/2013 (H7N9) (from Minhang RL market (RLo1).

Sequences of eight RNA segments of $\mathrm{CNO}_{2}, \mathrm{CNO}_{1}$ and TYo1 viruses were submitted to GenBank under accession numbers KF918656-KF918663, KF609516KF609523 and KF918664-KF918671, respectively. Sequences of the five RNA segments - polymerase $(\mathrm{PA})$, haemagglutinin $(\mathrm{HA})$, neuraminidase (NA), matrix protein (MP), non-structural protein (NS) - of RL01 virus were submitted to GenBank under accession numbers KJ572519-KJ572523. Eight gene segments from Case A (CNo2) in this study were most similar to those of Case B isolates (CNo1) ( $\geq 99.9 \%$ ). Phylogenetic analysis of the HA genes revealed that $\mathrm{CNO}_{2}$ and $\mathrm{CNO}_{1}$ strains were in one branch, distinctly separate from other human $\mathrm{A}\left(\mathrm{H}_{7} \mathrm{~N} 9\right)$ strains isolated in Shanghai (Figure 2). Both homology and phylogenetic analysis indicated that $\mathrm{CNO} 2$ possessed a similar genetic constellation as CNO1. The HA genes of the TY01 and RL01 strains were $99.6 \%$ similar by MegAlign method, which suggests the possibility that the $\mathrm{A}\left(\mathrm{H}_{7} \mathrm{~N}\right.$ ) $)$-positive chickens in these two markets could have been from the same source. With regard to the NA gene, $\mathrm{CNO}_{2}, \mathrm{CNO}_{1}$ and TY01 strains were located in the same large branch whereas RL01 was in another branch, which indicates that the NA gene of this novel avian influenza virus may come from different strains.

Similar to most human $\mathrm{A}\left(\mathrm{H}_{7} \mathrm{~N} 9\right)$ viruses, $\mathrm{CNo}_{2}$ and $\mathrm{CNo}_{1}$ acquired the ability to bind to human-like receptors with the substitutions G186V and Q226L in the HA protein ( $\mathrm{H}_{3}$ numbering) $[22,23]$. The 69-73 amino acid deletion was also presented in the NA gene ( $\mathrm{N} 2$ numbering).
Base pairs 1-429 of CNo1 were not sequenced, so full data are not available on the sequence or any deletions in the NA gene of this isolate.

The presence of lysine at amino acid 294 of the NA gene in the $\mathrm{CNo}$ strain indicates possible resistance to oseltamivir [24], whereas arginine was maintained at this position in the $\mathrm{CNO} 2 \mathrm{NA}$ gene, indicating its sensitivity to neuraminidase inhibitors [25]. However, both $\mathrm{CNO}_{1}$ and $\mathrm{CNO}_{2}$ had an $\mathrm{S}_{31} \mathrm{~N}$ mutation in the $\mathrm{M}_{2}$ protein, which confers resistance to adamantine. No truncated $\mathrm{PB} 1-\mathrm{F}_{2}$, associated with increased virulence $[26,27]$, was observed in $\mathrm{CNO} 1$ and $\mathrm{CNo2}$. Aspartic acid at $\mathrm{PB} 2$ residue 701 (present in $\mathrm{CNO} 1$ and $\mathrm{CNO} 2$ ) is associated with reduced transmissibility [28]. Amino acid $627 \mathrm{~K}$ was present in $\mathrm{PB} 2$ of $\mathrm{CNO} 1$ and $\mathrm{CN} 02$, but amino acid $627 \mathrm{E}$ was detected in TYo1 (E627K is associated with increased virulence $[29,30]$ ).

\section{Close contacts}

An additional 27 persons, including 22 medical personnel, four relatives and a friend, were identified as close contacts. All but one - a sibling of Case A - underwent 10 days of medical observation and did not develop acute respiratory symptoms. The sibling, in their early 50s, escorted Case A to an outpatient appointment on 1 April, cleaned her corpse without protection and attended the funeral of Case A on 3 April. This patient subsequently developed a fever of $37.6{ }^{\circ} \mathrm{C}$, headache and sore throat on 4 April and was admitted on 5 April, but recovered and was discharged on 9 April. The patient was administered oseltamivir from 5 to 9 April ( $75 \mathrm{mg}$ twice daily). The patient reported no history of exposure to live poultry in a wet market or other symptomatic individuals two weeks before the onset of symptoms. Throat swabs collected from the patient on the first day of medical observation were all negative for $\mathrm{A}(\mathrm{H} 7 \mathrm{~N} 9)$ by real-time RT-PCR.

Of the 27 close contacts, 14 were sampled at both acute phase and follow-up phase (four weeks after last contact); the other 13 close contacts chose not to be sampled for paired sera.

Nine of the 14 close contacts' acute serum samples were positive in the $\mathrm{HI}$ assay, with titres $\geq 40$. The $M N$ assay was used for further confirmation of the nine HI-positive serum samples. Only one acute serum was positive, with a titre of 20 : the other eight had an MN titres10. Follow-up sera of all 14 were negative for $\mathrm{A}\left(\mathrm{H}_{7} \mathrm{~N} 9\right)$ antibodies in the $\mathrm{HI}$ assay.

Details of the type of exposure of the close contacts and sera collection are shown in Table 2.

\section{Discussion}

The epidemiological and clinical features described here are most consistent with another family cluster of avian influenza $\mathrm{A}\left(\mathrm{H}_{7} \mathrm{~N} 9\right)$ in Shanghai, China. A similar clinical picture was seen in both cases, which provides 
Type of exposure and sera collection of 27 close contacts of two cases of influenza A(H7N9) infection, Shanghai, China, March-June 2013

\begin{tabular}{|c|c|c|c|c|c|}
\hline \multirow{3}{*}{ Characteristic } & \multicolumn{5}{|c|}{ Close contacts } \\
\hline & \multicolumn{2}{|c|}{ Only exposed to Case A } & \multicolumn{2}{|c|}{ Only exposed to Case B } & \multirow{2}{*}{$\begin{array}{c}\begin{array}{c}\text { Exposed to both } \\
\text { cases }\end{array} \\
\begin{array}{c}\text { Household } \\
(n=2)\end{array}\end{array}$} \\
\hline & $\begin{array}{l}\text { Household } \\
\qquad(n=1)\end{array}$ & $\begin{array}{c}\text { Healthcare } \\
\text { workers } \\
(\mathrm{n}=22)\end{array}$ & $\begin{array}{l}\text { Household } \\
\qquad(\mathrm{n}=1)\end{array}$ & $\begin{array}{l}\text { Social } \\
(\mathrm{n}=1)\end{array}$ & \\
\hline Age range in years & $505^{c}$ & $28-52$ & $505^{c}$ & $50 s^{c}$ & $50-56$ \\
\hline Sex (male) & o & 8 & 0 & 1 & 0 \\
\hline \multicolumn{6}{|l|}{ Possible exposure } \\
\hline Contact with poultry & 0 & 0 & 0 & 0 & 0 \\
\hline Visited wet market & 0 & 3 & 0 & 0 & 0 \\
\hline \multicolumn{6}{|l|}{ Type of contact with $\mathrm{A}\left(\mathrm{H}_{7} \mathrm{~N} 9\right)$ cases } \\
\hline Provided direct care $^{\mathrm{d}}$ & 1 & 2 & 1 & 0 & 2 \\
\hline Close physical contact ${ }^{\mathrm{e}}$ & 1 & 21 & 1 & 0 & 2 \\
\hline Exposed to case ( $\$ 1$ metre) & 1 & 22 & 1 & 0 & 2 \\
\hline $\begin{array}{l}\text { Contact with serum, respiratory or faecal } \\
\text { secretions of case }\end{array}$ & 0 & 8 & 0 & 0 & 1 \\
\hline Duration of exposure to casein hours (range) & $1^{\mathrm{c}}$ & $1(0.2-8)$ & $13^{c}$ & $1^{c}$ & $10.5(6.5-15)$ \\
\hline \multicolumn{6}{|l|}{ Personal protection equipment used } \\
\hline N95 respirator & 0 & 0 & 0 & 0 & 0 \\
\hline Surgical mask & o & 22 & o & o & o \\
\hline Goggles & 0 & 0 & 0 & 0 & 0 \\
\hline Face shield & 0 & 0 & 0 & 0 & 0 \\
\hline Gloves & 0 & 10 & 0 & 0 & 0 \\
\hline Gowns & 0 & 22 & 0 & 0 & 0 \\
\hline \multicolumn{6}{|l|}{ Symptoms } \\
\hline Febrile respiratory symptoms & 0 & 0 & 0 & 0 & 1 \\
\hline \multicolumn{6}{|l|}{ Serum collection } \\
\hline Paired sera samples collected & 0 & 13 & 0 & 1 & 0 \\
\hline $\begin{array}{l}\text { Time in days from last exposure to acute serum } \\
\text { collection for paired sera in days (range) }\end{array}$ & NA & $1(1-2)$ & NA & 0 & NA \\
\hline $\begin{array}{l}\text { Time in days from last exposure to convalescent } \\
\text { serum collection for paired sera in days (range) }\end{array}$ & NA & $21(21-25)$ & NA & $13^{c}$ & NA \\
\hline
\end{tabular}

NA: not applicable.

a Close contacts were defined as individuals known to have been within 1 metre or to have had contact with the serum, respiratory or faecal secretions of a case of influenza $\mathrm{A}\left(\mathrm{H}_{7} \mathrm{~N} 9\right)$ infection without having used effective protective equipment at any time from one day before the symptoms onset of the case to the day the case was placed in isolation or died [13].

b Data are numbers of close contacts unless otherwise indicated.

c No range given as only one close contact.

d Provided care for the patient and had the possibility of coming into contact with respiratory secretions or faecal material.

e Within 1 metre and in contact with the patient without personal protection.

support to the hypothesis that the same pathogen caused both illnesses.

The origin of infection for the index case was plausibly live poultry in her local wet market, acquiring $\mathrm{A}\left(\mathrm{H}_{7} \mathrm{~N} 9\right)$ from the environment during the course of her daily visit to the market. Visiting a live poultry market, where avian influenza A viruses can be maintained and amplified [31], is a known risk factor for $\mathrm{A}\left(\mathrm{H}_{5} \mathrm{~N}_{1}\right)$ infection in mainland China [32] and Hong Kong [33]. The Ministry of Agriculture in China announced that
$A\left(\mathrm{H}_{7} \mathrm{~N} 9\right)$ virus detected from poultry specimens from markets in Shanghai had a high degree of similarity with the $\mathrm{A}\left(\mathrm{H}_{7} \mathrm{~N} 9\right)$ virus isolated from patients on $4 \mathrm{April}$ [34]. After live poultry markets were shut down, the number of reports of fatal cases of $\mathrm{A}\left(\mathrm{H}_{7} \mathrm{~N} 9\right)$ virus infection dramatically diminished in Shanghai [21]. Before the poultry markets were disinfected, environmental samples collected in the market that Case A visited daily tested positive for avian influenza $A\left(\mathrm{H}_{7} \mathrm{N9}\right)$, which supports the hypothesis that the local wet market was the source of the infection in this case. 
Several pieces of epidemiological evidence gathered in the family cluster investigations support the origin of infection for Case $B$ being the virus transmitted from the index patient (his wife). First, he developed symptoms six days after the onset of his wife's symptoms and had provided care for her on each of these six days. Influenza virus incubation period is generally two to five days [35]. Second, during the course of his wife's illness, Case B was in close and regular contact with her, including eating and living together and providing unprotected bedside care. Prolonged and direct exposure to his critically ill wife made person-to-person spread of the virus possible. Third, Case B never visited the market and had not purchased or eaten poultry two weeks before the onset of his symptoms. Pigeons found in the community where the couple resided were negative for $A\left(\mathrm{H}_{7} \mathrm{~N} 9\right)$. Therefore it is highly unlikely that the novel virus was transmitted from pigeons or poultry to the secondary case in this family cluster.

The sequence comparison showed high similarity between the virus strains from samples collected from the two cases. Gene similarity analysis and phylogenetic analysis showed that Case B was likely to be the secondary case in this household infection. Genetic analysis supports the hypothesis that this was another family cluster of avian influenza infection [8].

One close contact developed mild symptoms during the medical observation phase, but real-time RT-PCR and $\mathrm{HI}$ assay ruled out the possibility of $A\left(\mathrm{H}_{7} \mathrm{~N} 9\right)$ virus infection. An acute serum sample from another close contact tested positive at a 1:20 dilution in the MN assay, but no fourfold elevation was detected in the follow-up serum. Other close contacts did not develop acute respiratory symptoms during the 10 days of medical observation, with all other paired sera testing negative for $\mathrm{A}\left(\mathrm{H}_{7} \mathrm{~N} 9\right)$ antibodies.

We previously found that only two of 440 close contacts of 32 confirmed cases of $\mathrm{A}\left(\mathrm{H}_{7} \mathrm{~N} 9\right)$ virus infection developed fever, cough or other respiratory symptoms in Shanghai in 2013 (data not shown). Given this finding and the fact that no further transmission was observed in the family cluster studied here, we speculate that human-to-human transmission of this novel avian $\mathrm{A}\left(\mathrm{H}_{7} \mathrm{~N} 9\right)$ virus is limited. Even if, as seems likely, Case $B$ was infected by the same virus that infected his wife, transmission arose following very close, frequent and unprotected contact. In this instance, limited person-to-person transmission of avian influenza $\mathrm{A}\left(\mathrm{H}_{7} \mathrm{Ng}\right)$ virus possibly occurred in this couple, as documented for subtype $\mathrm{H}_{7}$ transmission in the Netherlands in 2003 [36]. Similar to $A\left(\mathrm{H}_{5} \mathrm{~N}_{1}\right)$ virus, $A\left(\mathrm{H}_{7} \mathrm{~N}_{9}\right)$ virus mainly affects the lower respiratory tract, sputum and endotracheal aspirates [37], which may lead to reduced virus shedding in the upper respiratory tract.

Whether susceptibility to severe influenza in humans is heritable or not is still controversial [38]. More than
$90 \%$ of $\mathrm{A}\left(\mathrm{H}_{5} \mathrm{~N}_{1}\right)$ case clusters have occurred in blood relatives [39]. Previous reports of family clusters of $\mathrm{A}\left(\mathrm{H}_{7} \mathrm{~N} 9\right)$ virus infection imply genetic susceptibility to this virus in a family. The cases in these family clusters were blood relatives. In contrast, however, the couple in our study were not blood relatives, which implies that prolonged, intense exposure to a sick person without any personal protective equipment can lead to human-to-human transmission of the virus to someone who is no more likely than anyone else in the population to share genes that make them more susceptible to infection. Thus, further in-depth study on genetic susceptibility to $A\left(\mathrm{H}_{7} \mathrm{~N} 9\right)$ virus infection is needed [40].

Taken together, our results indicate that human-tohuman transmission of $\mathrm{A}\left(\mathrm{H}_{7} \mathrm{~N} 9\right)$ virus most likely occurred between these two family members. Our investigation of their close contacts does not suggest that the virus has developed the ability to transmit readily and widely between humans. More urgent research is required to better understand the characteristics of the virus and determine its transmissibility between humans.

\section{Acknowledgements}

We thank the Shanghai Municipal Center for Animal Disease Control and Prevention for providing assistance in live poultry and homing pigeon sampling and detection. We thank the local government of Changning District for providing assistance with comprehensive field investigation. We thank all the participants of Jinan CDC for in-depth epidemiological survey. We thank the Shanghai Public Health Clinical Center for offering clinical information and collecting samples. We acknowledge the authors, originating and submitting laboratories of the sequences from GISAID's EpiFlu Database on which this research is based (see Figure 1). All submitters of the data may be contacted directly via the GISAID website www.gisaid.org.

This work was supported by Shanghai $\mathrm{H}_{7} \mathrm{~N}_{9}$ research funding (grant number2013QLGo07 and 2013QLG008), Shanghai Leading Talents Project to Fan Wu (grant number 2010-048), Key Disciplines Project to Fan Wu (grant number 12GWZX0702), to Zhengan Yuan (grant number 12GWZX0101), to Xi Zhang (grant number 12GWZX0801) and Leaders of Key Disciplines Project to Zhengan Yuan (grant number GWDTR201201).

Conflicts of interest

None declared.

Authors' contributions

Jiayu Hu, Yiyi Zhu, Jian Li, Zijian Feng and Fan Wu designed the protocol of investigation, set up the field epidemiology and clinical investigation, contacted all investigators; Baihui Zhao, Liguo Liu, Haoxiang Su, Zhen Teng were responsible for real-time RT-PCR testing, sequence analysis and serological assay, including the experimental design and data analysis; KaikaiGu, Wenhong Zhang and Songzhe Tang provided technical assistance for the epidemiological investigations and clinical data and helped to review the data. All other coauthors participated in collection and management of data. 


\section{References}

1. Gao R, Cao B, Hu Y, Feng Z, Wang D, Hu W, et al. Human infection with a novel avian-origin influenza $A\left(\mathrm{H}_{7} \mathrm{~N} 9\right)$ virus. N Engl J Med. 2013;368(20):1888-97. http://dx.doi.org/10.1056/ NEJMoa1304459

2. Bertran K, Pérez-Ramírez E, Busquets N, Dolz R, Ramis A, Darji $A$, et al. Pathogenesis and transmissibility of highly $\left(\mathrm{H}_{7} \mathrm{~N}_{1}\right)$ and low $\left(\mathrm{H}_{7} \mathrm{~N} 9\right)$ pathogenic avian influenza virus infection in redlegged partridge (Alectorisrufa). Vet Res. 2011;42:24. http:// dx.doi.org/10.1186/1297-9716-42-24

3. Belser JA, Bridges CB, Katz JM, Tumpey TM. Past, present, and possible future human infection with influenza virus $A$ subtype H7. Emerg Infect Dis. 2009;15(6):859-65. http://dx.doi. org/10.3201/eid1506.090072

4. World Health Organization (WHO). Map and epidemiological curve of confirmed human cases of avian influenza $A\left(\mathrm{H}_{7} \mathrm{~N} 9\right)$. Geneva: WHO. [Accessed 5 May2014).Available from: http://www.who.int/influenza/human animal_interface/ influenza_h7n9/Data Reports/en/

5. Gambotto A, Barratt-Boyes SM, de Jong MD, Neumann G, Kawaoka Y. Human infection with highly pathogenic $\mathrm{H}_{5} \mathrm{~N}_{1}$ influenza virus. Lancet. 2008;371(9622):1464-75. http://dx.doi. org/10.1016/S0140-6736(08)60627-3

6. Nguyen TH, Farrar J, Horby P. Person-to-person transmission of influenza A (H5N1). Lancet.2008;371(9622):1392-4. http:// dx.doi.org/10.1016/So140-6736(08)60494-8

7. Ungchusak K, Auewarakul P, Dowell SF, Kitphati R, Auwanit W, Puthavathana $\mathrm{P}$, et al. Probable person-to-person transmission of avian influenza A (H5 $\left.\mathrm{H}_{1}\right)$. N Engl J Med. 2005;352(4):333-40. http://dx.doi.org/10.1056/NEJMoa044021

8. Wang H, Feng Z, Shu Y, Yu H, Zhou L, Zu R, et al. Probable limited person-to-person transmission of highly pathogenic avian influenza $\mathrm{A}\left(\mathrm{H}_{5} \mathrm{~N}_{1}\right)$ virus in China. Lancet. 2008;371(9622):1427-34. http://dx.doi.org/10.1016/ So140-6736(08)60493-6

9. Li Q, Zhou L, Zhou M, Chen Z, Li F, Wu H, et al. Epidemiology of human infections with avian influenza $\mathrm{A}\left(\mathrm{H}_{7} \mathrm{~N} 9\right)$ virus in China. N Engl J Med. 2014;370(6):520-32. http://dx.doi.org/10.1056/ NEJMoa1304617

10. Qi X, Qian YH, Bao CJ, Guo XL, Cui LB, Tang FY, et al. Probable person to person transmission of novel avian influenza $\mathrm{A}\left(\mathrm{H}_{7} \mathrm{~N} 9\right)$ virus in Eastern China, 2013: epidemiological investigation. BMJ. 2013;347:f4752. http://dx.doi.org/10.1136/ bmj.f 4752

11. Liu D, Shi W, Shi Y, Wang D, Xiao H, Li W, et al. Origin and diversity of novel avian influenza $\mathrm{A} \mathrm{H} 7 \mathrm{~N} 9$ viruses causing human infection: phylogenetic, structural, and coalescent analyses. Lancet.2013;381(9881):1926-32. http://dx.doi. org/10.1016/S0140-6736(13)60938-1

12. Center for Infectious Disease Research and Policy (CIDRAP). $\mathrm{H}_{7} \mathrm{~N} 9$ in China; Low global flu activity; Recombinant flu vaccine contract. Minneapolis, MN: CIDRAP. [Accessed 17 Jun 2014]. Available from: http://www.cidrap.umn.edu/ news-perspective/2014/06/flu-scan-jun-17-2014

13. National Health and Family Planning Committee of China. [Influenza A $(\mathrm{H} 7 \mathrm{~N} 9)$ epidemic control plan (3rd edition)]. Beijing: National Health and Family Planning Committee of China; 2014. [Accessed 5 Jan 2014]. Chinese. Available from: http://www.nhfpc.gov.cn/jkj/s3577/201401/8c1828375a7949c d85454a76bb84f23a.shtml

14. World Health Organization (WHO). Real-time RT-PCR Protocol for the detection of avian influenza $A\left(\mathrm{H}_{7} \mathrm{~N} 9\right)$ virus. 8 April 2013. Updated on 15 April 2013. Geneva: WHO. [Accessed 5 Jan 2014]. Available from: http://www.who.int/influenza/gisrs laboratory/cnic_realtime_rt_pcr_protocol_a_h7n9.pdf?ua=1

15. Zhao B, Zhang X, Zhu W, Teng Z, Yu X, Gao Y, et al. Novel avian influenza $\mathrm{A}\left(\mathrm{H}_{7} \mathrm{~N} 9\right)$ virus in tree sparrow, Shanghai, China, 2013. Emerg Infect Dis. 2014;20(5):850-3. http://dx.doi. org/10.3201/eid2005.131707

16. Clewley JP, Arnold C. MEGALIGN. The multiple alignment module of LASERGENE. Methods Mol Biol. 1997;70:119-129.

17. Sohpal VK, Dey A, Singh A.MEGA biocentric software for sequence and phylogenetic analysis: a review. Int J Bioinform Res Appl. 2010;6(3): 230-40. http://dx.doi.org/10.1504/ IJBRA.2010.034072

18. Stephenson I, Wood JM, Nicholson KG, Zambon MC. Sialic acid receptor specificity on erythrocytes affects detection of antibody to avian influenza haemagglutinin. J Med Virol. 2003;70(3):391-8. http://dx.doi.org/10.1002/jmv.10408

19. World Health Organization (WHO). Laboratory procedures. Serological detection of avian influenza A ( $77 \mathrm{N9})$ virus infections by modified horse red blood cells haemagglutination-inhibition assay. 20 December 2013. Geneva: WHO. [Accessed 5 Jan 2014]. Available from: http:// www.who.int/influenza/gisrs_laboratory/cnic_serological_ diagnosis_hai_a_h7n9_20131220.pdf

20. World Health Organization (WHO). Laboratory procedures. Serological detection of avian influenza $\mathrm{A}\left(\mathrm{H}_{7} \mathrm{Ng}\right.$ ) infections by microneutralization assay. 23 May 2013. Geneva: WHO. [Accessed 5 Jan 2014]. Available from: http://www.who.int/ influenza/gisrs_laboratory/cnic_serological_diagnosis_ microneutralization_a_h7n9.pdf? ua =1

21. Yu H, Wu JT, Cowling BJ, Liao Q, Fang VJ, Zhou S, et al. Effect of closure of live poultry markets on poultry-to-person transmission of avian influenza $\mathrm{AH}_{7} \mathrm{~N}$ g virus: an ecological study. Lancet.2014;383(9916):541-8. http://dx.doi.org/10.1016/ S0140-6736(13)61904-2

22. Herfst S, Schrauwen EJ, Linster M, Chutinimitkul S, de Wit E, Munster VJ, etal. Airborne transmission of influenza $\mathrm{A} / \mathrm{H}_{5} \mathrm{~N}_{1}$ virusbetween ferrets. Science.2012;336(6088):1534-41. http:// dx.doi.org/10.1126/science.1213362

23. Imai M, Watanabe T, Hatta M, Das SC, Ozawa M,ShinyaK,etal. Experimental adaptation of an influenzaH 5 HA confers respiratory droplet transmissionto a reassortant $\mathrm{H}_{5} \mathrm{HA} /$ H1N1virus in ferrets. Nature. 2012;486(7403):420-8.

24. Hu Y, Lu S, Song Z, Wang W, Hao P, Li J, et al. Association between adverse clinical outcome in human disease caused by novel influenza $\mathrm{A} \mathrm{H} 7 \mathrm{~N} 9$ virus and sustained viral shedding and emergence of antiviral resistance. Lancet. 2013;381(9885):2273-9. http://dx.doi.org/10.1016/ So140-6736(13)61125-3

25. Yuen KY.Solving the mystery of $\mathrm{H}_{7} \mathrm{~N} 9$ by crystal balls. Cell Res. 2013;23(12):1335-6. http://dx.doi.org/10.1038/cr.2013.150

26. Košík I, Krejnusová I, Práznovská M, Russ G. The multifaceted effect of PB1-F2 specific antibodies on influenza $A$ virus infection.Virology. 2013;447(1-2):1-8. http://dx.doi. org/10.1016/j.virol.2013.08.022

27. Alymova IV, Samarasinghe A, Vogel P, Green AM, Weinlich $R$, McCullers JA.A novel cytotoxic sequence contributes to influenza A viral protein $\mathrm{PB}_{1}-\mathrm{F}_{2}$ pathogenicity and predisposition to secondary bacterial infection. J Virol. 2014;88(1):503-15. http://dx.doi.org/10.1128/JVI.01373-13

28. Zhou B, Pearce MB, Li Y, Wang J, Mason RJ, Tumpey TM, et al. Asparagine substitution at PB2 residue 701 enhances the replication, pathogenicity, and transmission of the 2009 pandemic $\mathrm{H}_{1} \mathrm{~N}_{1}$ influenza A virus.PLoS One. 2013;8(6):e67616 http://dx.doi.org/10.1371/journal.pone.0067616

29. Zhang H, Li X, Guo J, Li L, Chang C, Li Y,et al. The PB2 E627K mutation contributes to the high polymerase activity and enhanced replication of $\mathrm{H}_{7} \mathrm{~N} 9$ influenza virus. J Gen Virol. 2014;95(Pt 4):779-86. http://dx.doi.org/10.1099/vir.0.061721-0

30. Jonges M, Welkers MR, Jeeninga RE, Meijer A, SchneebergerP, Fouchier RA, et al. Emergence of the virulence-associated PB2 E627K substitution in a fatal human case of highly pathogenic avian influenza virus $\mathrm{A}\left(\mathrm{H}_{7} \mathrm{~N} 7\right)$ infection as determined by Illumina ultra-deep sequencing. J Virol. 2014;88(3):1694-702. http://dx.doi.org/10.1128/JVI.02044-13

31. Webster RG. Wet markets--a continuing source of severe acute respiratory syndrome and influenza? Lancet. 2004;363(9404):234-6. http://dx.doi.org/10.1016/ S0140-6736(03)15329-9

32. Yu H, Feng Z, Zhang X, Xiang N, Huai Y, Zhou L, et al. Human influenza A $\left(\mathrm{H}_{5} \mathrm{~N}_{1}\right)$ cases, urban areas of People's Republic of China, 2005-2006.Emerg Infect Dis. 2007;13(7):1061-4. http:// dx.doi.org/10.3201/eid1307.061557

33. Mounts AW, Kwong H, Izurieta HS, Ho Y, Au T, Lee M, et al. Case-control study of risk factors for avian influenza $A\left(\mathrm{H}_{5} \mathrm{~N}_{1}\right)$ disease, Hong Kong, 1997.J Infect Dis. 1999;180(2):505-8. http://dx.doi.org/10.1086/314903

34. Ministry of Agriculture (MOA). [The Ministry of Agriculture detected the $\mathrm{H}_{7} \mathrm{~N} 9$ avian influenza positive in samples from Shanghai market]. Beijing: MOA.[Accessed 5 Jan2014]. Chinese. Available from: http://www.moa.gov.cn/zwllm/yjgl/ yqfb/201304/t20130404_3424956.htm

35. Hui DS. Review of clinical symptoms and spectrum in humans with influenza A/H5 $\mathrm{N}_{1}$ infection. Respirology. 2008;13Suppl 1:S10-3. http://dx.doi.org/10.1111/j.1440-1843.2008.01247.x

36. Du Ry van BeestHolle M, Meijer A, Koopmans M, de Jager CM. Human-to-human transmission of avian influenza $A / H 7 N 7$, The Netherlands, 2003. Euro Surveill. 2005;10(12): pii=584.

37. Chen Y, Liang W, Yang S, Wu N, Gao H, Sheng J, et al. Human infections with the emerging avian influenza $\mathrm{A} \mathrm{H} 7 \mathrm{~N}$ 9 virus from wet market poultry: clinical analysis and characterisation of viral genome. Lancet. 2013;381(9881):1916-25. http://dx.doi. org/10.1016/S0140-6736(13)60903-4

38. Horby P, Nguyen NY, Dunstan SJ, Baillie JK. The role of host genetics in susceptibility to influenza: a systematic review. PLoS One. 2012;7(3):e33180. http://dx.doi.org/10.1371/journal. pone. 0033180 
39. Writing Committee of the Second World Health Organization

Consultation on Clinical Aspects of Human Infection with Avian

Influenza A ( $\left.{ }_{5} \mathrm{~N}_{1}\right)$ Virus, Abdel-Ghafar AN, Chotpitayasunondh

T, Gao Z, Hayden FG, Nguyen DH, et al. Update on avian

influenza $A\left(\mathrm{H}_{5} \mathrm{~N}_{1}\right)$ virus infection in humans. N Engl J Med.

2008;358(3):261-73. http://dx.doi.org/10.1056/NEJMra0707279

40. Pitzer VE, Olsen SJ, Bergstrom CT, Dowell SF, Lipsitch M. Little evidence for genetic susceptibility to influenza $A\left(\mathrm{H}_{5} \mathrm{~N}_{1}\right)$ from

family clustering data. Emerg Infect Dis. 2007;13(7):1074-6.

http://dx.doi.org/10.3201/eid1307.061538 